\title{
The Effectiveness of Castration And Seed Sources on the Growth and Production of Strawberry Plants (Fragaria $x$ ananassa var duchesne)
}

\author{
Susilawati Hasibuan' ${ }^{1}$, Syahbudin Hasibuan ${ }^{1}$, and Ellen L. Panggabean ${ }^{1}$ \\ ${ }^{1}$ Faculty of Agriculture, University of Medan Area, Indonesia
}

\begin{abstract}
Research on The Effectivity Of Castration And Seed Sources To The Growth And Production Of Strawberry Crops (Fragaria $x$ ananassa var duchesne). Objectives to determine the effect of castration and seed sources in encouraging the growth and production of strawberry plants (Fragaria $x$ ananassa var duchesne). The research was conducted at Fruit Plant Experiment Center of Berastagi Fruit Experiment Garden, Medan Berastagi road 60 kilometer, Karo district with \pm 1200 meters above sea level. The study was conducted from May 2014 until August 2014, using Factorial Randomized Block Design (RAK), with four replications, 6 combinations to obtain 24 plant plots from all combinations and replications. The first factor to be tested was castration ie $K O=$ without castration, $K 1=$ using castration. The second factor that tested is Source of seed of strawberry plant that is S1 = source of seed from seedling, S2 = source of seed from Sulur in book 1, S3 = source of seed from Sulur in book 2. The results showed that the castration was very significant in the observation of fruit weight of cultivation with 13.11 gram (K1S1) weight and no significant effect on production per plot, but the average yield of fruit weight per plot showed a high yield of 176.13 grams (K1S1). In general, this study showed castration treatment had an effect in increasing strawberry fruit weight to all sources of seeds.
\end{abstract}

Keywords : strawberries, kastrasi, source of seeds, saplings, sulur

\section{Introduction}

Strawberries are a very interesting type of fruit, and have been known since Roman times. Its allure lies in the striking red color of the fruit with sweet and fresh sour taste. Strawberries contain Ellagic Acid as an antioxidant. In several studies Ellagic Acid has been shown to inhibit tumor growth in the lungs, asephagus, breast, cervix and tongue. Research in American strawberries can reduce the risk of cancer from cigarette smoke. Strawberries are believed to be traditional medicines, because they have anti-bacterial properties and are used as a cleanser for the digestive system. Strawberries are a type of fruit that is almost indigestible but contains a lot of vitamin C. Strawberries are easily decayed so they are rarely stored for long but are eaten directly after being picked (Siswono, 2005).

Strawberry fruit has a high economic value and is currently a fruit that is very popular with many people. This fruit can be consumed as fresh fruit, canned fruit, juice, jam, syrup, lunkhead, ice cream mixture and yogurt mixture (Directorate of Fruit Plants, 2002). Plants originating from the American continent, then spread to Europe and Asia (Directorate of Fruit Plants, 2002).

The demand for strawberries in Southeast Asia is quite high. In Indonesia alone, there are many emerging strawberry-flavored businesses, from strawberry walks, cafes, to factory outlets. The volume of strawberry production increases every year. According to the Central Bureau of Statistics (2012), the volume of strawberry production in 2011 was 41,035 tons, a $68 \%$ increase from 2010 which was only 24,856 tons. Domestic strawberry production has 
not been able to cover the high market demand so that in 2011 there was an increase in strawberry imports by $24.7 \%$, from 452 tons to 564 tons. (Central Statistics Agency, 2012).

However, strawberry production in Indonesia is still very low. The productivity of Indonesian strawberries averages only 6-7 tons / ha / year while strawberry productivity according to the literature can reach 57 tons / ha / year. (Hanif and Hasyim, 2012 in Aswita 2007). One reason is that the cultivation technique is not right, the strawberry cultivars used are still low productivity, as well as the presence of pests and diseases. These production constraints result in low levels of productivity. The factors for increasing productivity are improving crop cultivation techniques.

According to Ferdy (2008), in the world of agriculture and in the sub sciences of plant breeding in particular there is something called the castration. Castration is a technique used by breeders to increase the productivity of glorified plants, by removing strawberry flowers from their receptacel. Based on the above, a research on flower castration was conducted, which considered flower castration to be a factor that influenced the growth and production of strawberry plants of various types of seeds. The aim of the study was to determine the effect of castration and source of seeds in promoting the growth and production of strawberry plants (Fragaria x ananassa var duchesne).

\section{Methodology}

The materials used in this study were: strawberry varieties of Sweet charlie, cow manure, NPK fertilizer and water. The tools used in this study were hoes, babybag size $14 \mathrm{~cm}$ x $15 \mathrm{~cm}$, scissors, tweezers, meters, black silver plastic mulch, handsprayer, scales, milk cans, parallel pipes, loose, sample / plot boards, documentation tools (camera), plastic buckets and stationery used during the study.

This research was conducted using Factorial Randomized Block Design (RBD) consisting of two factors, namely: (1) Treatment factors for castration (K notation) were carried out with 2 treatment levels, namely: $\mathrm{K} 0=$ Without castration, $\mathrm{K} 1=$ Using castration. (2) Treatment factors on the source of plant seeds with (S Notation) are carried out with 3 levels of treatment, namely: S1 = Source of seed from seedlings, $\mathrm{S} 2=$ Source of seed from stolon / tendrils in book 1, S3 = Source of seed from stolon in the second book

The implementation of research includes several stages, namely: (1) Seed Provision, according to Sudarma (2013), vegetative seeds for strawberry cultivation in the garden, selected parent plants should be healthy and productive. The preparation of seedlings of saplings and stolons is as follows:

Select parent plants which contain at least 1 sapling that has 3 leaves, then the clump is dismantled. Each sapling is planted in a $10 \mathrm{~cm} \times 12 \mathrm{~cm}$ babybag containing soil. After that the seeds are transferred to the nursery for 2 weeks and given a shade of plastic, by watering in the morning and evening.

Select the parent plant that has the first and second tendrils. Cut both of the tendrils from the parent plant, then plant them in a $10 \mathrm{~cm} \times 12 \mathrm{~cm}$ babybag containing soil. After that the seeds are transferred to the nursery for 2 weeks, and given shade in the form of plastic, by watering in the morning and evening.

(2) Soil processing, the land used is cleaned of weeds especially those that have stems and tubers that can interfere with the research process. Dumping is done by using hoes, then 
the land is divided into 6 groups each consisting of 4 experimental plots and forming beds with the size of the experimental plots each measuring $100 \mathrm{~cm} \times 150 \mathrm{~cm}$, height $30 \mathrm{~cm}$, spacing of $30 \times 30 \mathrm{~cm}$, distance between plot of $50 \mathrm{~cm}$, and distance between replications 50 $\mathrm{cm}$. The soil was given as much as 30 tons / ha $(4.5 \mathrm{~kg} / \mathrm{plot})$ of basic cow manure and 1.25 tons / ha (187.5 / plot) of NPK. Fertilizers are applied by sprinkling and stirring evenly on the entire surface of the beds, then let stand for 7 days.

(3) Giving Mulch, mulching aims to maintain soil moisture, maintain soil temperature in subtropical soil, prevent weeds from occurring and keep the fruit clean and indirectly located on the ground. Punching is done by using heated milk cans and then placed on mulch according to the treatment with $30 \mathrm{~cm}$ spacing (Soemardi, 1997).

Parameters observed include:

\section{Number of Leaves per Plant (Strands)}

Calculation of the number of leaves of the sample plant starts from the lowest leaf until the leaf on the highest stem that has been opened perfectly. Calculations are done 1 week after the plants are transferred to beds until 8 weeks after planting. With intervals of 1 week. Early Flowering Period (Day After Planting)

Strawberry seedlings from seedlings and stolons start flowering at the age of 2 months after planting. Observation of flowering plants if $75 \%$ of the sample plants in each plot have issued flowers. At the beginning of flowering on a strawberry plant whose buds begin to open, the whole flower is removed from the receptacle. Castration is carried out in the morning (09.00 WIB).

\section{Number of Fruits Per Stalk (Fruit)}

The number of fruits per stalk was calculated in each experimental plot on the sample plants at harvest and separated according to each plot.

\section{Fruit Weight}

Fruit weight parameters were carried out to determine the effect of the treatment, then weighing the weight of the sample plant $(\mathrm{g})$ was done, by weighing the weight of the fruit produced from the sample plants in each plot. Weighing the weight of fruit production per plot $(\mathrm{g})$ by weighing the weight of fruit produced from each plot.

\section{Fruit Production Per Hectare (ton / ha)}

Production per hectare is obtained after the production per plot is known, namely by converting production per plot to hectares. Perektar production is calculated using the formula:

Production per hectare $=\frac{\text { luassatuhektar }}{\text { luasplotpercobaan }} \times$ number of production per plot

\section{Result and Discussion}

The results showed that the cultivation of strawberries with different castration treatments and seed sources obtained different results at each observation. Can be seen from each parameter observed as follows: 


\section{Number of Leaves per Plant (Strands)}

From the variance table shows that the administration of basic fertilizer (manure) and source of seed has no significant effect on the number of leaves at all ages of observation. Likewise, the interaction between these treatments had no significant effect on the number of leaves at all ages of observation. The average number of leaves of strawberry plants aged 1 , up to 6 MSPT can be seen in Table 1. Seen in Table 1 different treatment of castration and seed sources and addition of basic fertilizer (manure) to the parameters of the number of leaves of strawberry plants did not have significant effect on the fingerprint count. variety. This is because leaf growth is influenced by nutrients used by plants for the growth process, the appearance of leaves in strawberry plants means the appearance of shoots (stolon).

Table 1. Average Number of Leaves of Strawberry Plants Aged 1 to 6 MST

\begin{tabular}{lcccccc}
\hline Treatment & 1MST & 2MST & 3MST & 4MST & 5MST & 6MST \\
\hline K0S1 & 15.00 tn & 16.00 tn & 17.00 tn & $24.75 \mathrm{tn}$ & $28.50 \mathrm{tn}$ & $34.50 \mathrm{tn}$ \\
K0S2 & $16.00 \mathrm{tn}$ & $17.00 \mathrm{tn}$ & $18.00 \mathrm{tn}$ & $26.00 \mathrm{tn}$ & $30.25 \mathrm{tn}$ & $35.50 \mathrm{tn}$ \\
K0S3 & $16.25 \mathrm{tn}$ & $17.25 \mathrm{tn}$ & $18.25 \mathrm{tn}$ & $26.50 \mathrm{tn}$ & $32.75 \mathrm{tn}$ & $38.25 \mathrm{tn}$ \\
K1S1 & $16.25 \mathrm{tn}$ & $17.25 \mathrm{tn}$ & $18.25 \mathrm{tn}$ & $25.75 \mathrm{tn}$ & $31.00 \mathrm{tn}$ & $36.00 \mathrm{tn}$ \\
K1S2 & $16.00 \mathrm{tn}$ & $17.00 \mathrm{tn}$ & $18.00 \mathrm{tn}$ & $26.75 \mathrm{tn}$ & $31.00 \mathrm{tn}$ & $36.25 \mathrm{tn}$ \\
K1S3 & $16.00 \mathrm{tn}$ & $17.00 \mathrm{tn}$ & $18.00 \mathrm{tn}$ & $27.25 \mathrm{tn}$ & $29.00 \mathrm{tn}$ & $34.00 \mathrm{tn}$ \\
\hline
\end{tabular}

Note $:$ tn $=$ not real

From the results of the average can be seen the highest number of leaves 24.88 strands and the lowest 22.63 strands, where all treatments of planting strawberries using manure with the same dose, but only different sources of seeds (Table 2). All of this is due to the formation of leaves influenced by nutrients that are scattered by the plants by xylem vessels that diffuse from the roots and toward the vessel system, these compounds are used to form leaves characterized by cell division in the leaf tops, primary and secondary branches and on strawberry plants emergence of tendrils. (Salisbury and Cleon, 1998). In this study, the basic fertilizer treatment (the same dosage) on different sources of seed did not show differences in growth between all strawberry plants before the castration treatment of strawberry plants was carried out.

\section{Early Flowering Period (Day after planting)}

From the variance table, it can be seen that the treatment of castration shows very real results for the initial flowering period. Whereas the effect of the source of seed treatment is not real. However, the combination between the treatment of castration and the source of the seeds shows an unrealistic influence on the initial flowering period. The average initial flowering period for strawberries due to the treatment of castration and seed sources can be seen in Table 2. 
Table 2. Average Flowering Period of Strawberry Plants

\begin{tabular}{llll}
\hline Treatment & \multirow{2}{*}{$\begin{array}{c}\text { Early } \\
\text { Flowering } \\
\text { Period }\end{array}$} & \multicolumn{2}{c}{ Notation } \\
\cline { 3 - 4 } & & 0.05 & 0.01 \\
K0S1 & 34.50 & $\mathrm{c}$ & $\mathrm{C}$ \\
K0S2 & 45.25 & $\mathrm{ab}$ & $\mathrm{AB}$ \\
K0S3 & 42.71 & $\mathrm{a}$ & $\mathrm{A}$ \\
K1S1 & 33.67 & $\mathrm{c}$ & $\mathrm{C}$ \\
K1S2 & 43.42 & $\mathrm{ab}$ & $\mathrm{AB}$ \\
K1S3 & 47.83 & $\mathrm{a}$ & $\mathrm{A}$ \\
\hline
\end{tabular}

Note: Numbers with the same letters in the same column are not significantly different at the level of $\alpha=0.05 \%$ (lowercase) and $\alpha 0.01$ (uppercase) based on the Duncan distance test (DMRT)

From Table 2 it can also be seen that the treatment of S1 shows a significant difference in all treatment levels, but it is assumed that the provision of basic fertilizers with the same dose at all treatment levels that make the initial flowering in S1 treatment (tillers) make faster and visually added condition of seedlings from tillers have many roots, while seeds from tendrils have little roots, so that faster growth of seedlings comes from saplings compared to seeds from tendrils

This is because the seeds from the saplings have a development that is identical to the parent, which is characterized by stronger absorption of roots from tendrils. Seedlings from saplings carry out nutrient absorption by diffusion by the roots faster than the seedlings from tendrils. The diffusion process is the transfer of mineral salts from high concentrations to low concentrations through semipermiable membranes at the roots of plants (Salisbury and Cleon, 1992).

Nutrients that are scattered through the diffusion process are $\mathrm{N}, \mathrm{P}$, and $\mathrm{K}$, where they increase growth in the vegetative period of the plant. Sarief (1986) in Millya (2007), revealed that nitrogen forms important compounds such as chlorophyll, nucleic acids and enzymes, therefore nitrogen is needed in relatively large amounts at each stage of vegetative growth, namely bud formation or stem and leaf development. The availability of sufficient amounts of $\mathrm{N}$ elements in plant tissue affects photosynthetic activity through the formation of chlorophyll. Therefore, if the chlorophyll content in the leaves is sufficiently available, the photosynthate produced through photosynthesis also increases. In the vegetative phase of the plants that have passed the age of initial growth where the plants have formed branches to absorb $\mathrm{N}$ faster and more so that the growth appears more significant (Salisbury and Cleon 1998).

Plant or plant growth is supported and influenced by several factors, namely nutrient ions or mineral salts which are absorbed by the leaves and carry out photosynthesis. Where absorption and photosynthesis will not run optimally if the leaf's fresh period is lower than the dry period of the leaves, the dry period itself becomes a more legitimate estimate to determine the clues that indicate the absence of growth, while the fresh period determines the growth of a plant because the fresh leaves occur Photosynthesis and greater absorption of salt and photosynthates affect plant production (Salisbury and Cleon, 1992). 
Plant production is very dependent on vegetative growth of plants (Lakitan, 2013). Flowering strawberry plants that can more quickly extend the crop harvest period, so that the production period is also getting longer. This condition is due to the provision of manure to meet the needs of the strawberry plant for flower formation. It requires $\mathrm{P}$ elements. $\mathrm{P}$ elements that play a role in the formation of proteins and minerals, and accelerate flowering and fertilization, where phosphates obtain cell energy sources (ATP) used in photosynthesis during reserve formation food so that Phosphate gives influence on food reserves in flowering and fruit enlargement (Agromedia, 2007). In addition to the factors above several other factors that influence the beginning of flowering, namely the environment that affects the formation of flowers, including temperature, duration of irradiation, and other environmental factors.

The temperature directly affects photosynthesis, respiration, nutrient water absorption and transpiration. The ideal temperature for strawberry growth is $180 \mathrm{C}-250 \mathrm{C}$. Wiryanta (2002) states that daily temperatures that exceed the optimum limit in plants can accelerate flowering. This condition is caused by plants collecting faster panes so that the plants can form faster flowers. According to Darjanto and Satifah (1984) flower formation is the transition of growth from the vegetative phase to the generative phase. The transition from the vegetative phase to the generative phase is partly determined by genotyping factors (hereditary nature) or internal factors and partly determined by external factors such as temperature, light, humidity and fertilization.

The number of flower stalks is influenced by plant genetics but is not influenced by water treatment this affects the number of fruit in the future. This shows that the genetic traits between plants are more prominent than water. The causes of differences in the nature of the origin of tillers are genetics, habitat (place of life), and availability of nutrients. According to Ginting (1991) that different plants from seedlings have different growths even though they are planted on the same soil. Dian (2013) also revealed that differences in plant origin resulted in differences in regulatory genes that influence the level of plant growth and development.

\section{Number of Fruits Per Stalk (Fruit)}

From the variance table, it can be seen that the source of the seedlings has a significant effect, while the castration treatment shows insignificant results on the number of stem fruits. However, the combination between the treatment of castration and the source of the seed showed no significant effect on the number of stem fruit. The average number of strawberry plants due to the treatment of castration and seed sources can be seen in Table 3. 
Table 3. Average Fruit of Strawberry Crops

\begin{tabular}{ll}
\hline \multicolumn{1}{c}{ Treatment } & \multicolumn{1}{c}{$\begin{array}{c}\text { Number of Fruit } \\
\text { Strings }\end{array}$} \\
\hline K0S1 & 18.75 \\
K0S2 & 19.125 \\
K0S3 & 17.75 \\
K1S1 & 16,87 \\
K1S2 & 20.62 \\
K1S3 & 18.25 \\
\hline
\end{tabular}

Note: Numbers with the same letters in the same column are not significantly different at the level of $\alpha=0.05 \%$ (lowercase) and $\alpha 0.01$ (uppercase) based on the Duncan distance test (DMRT).

The results of the observations are seen in the treatment of K0S2 which has a number of fruits 19.125 , K1S2 of 20.62 and the highest in the treatment of K1S2. This shows that the treatment of castration against the source of seedlings from tendrils does not affect the number of fruit crops. The amount of fruit itself is influenced by nutrients and environmental conditions. Nutrients make pegetative growth to the maximum and make plant availability in preparing plants to continue reproducing. The reproductive period is characterized by the appearance of flowers which then become fruit. Flowers that become fruit are more influenced by genetics and environment (temperature), where the temperature and volume of water.

The treatment of water volume also affects fruiting age, number of fruit crops, fruit weight per plant, and average weight per fruit. This is due to the generative phase of water deficit, so that the absorption of nutrients by the roots runs slowly and nutrient translocation to leaves is also slow. According to Sumarna (1998) that giving water to plants is adjusted to the type and age of the plant, because the type and age of the plant determines the number of different water requirements. Turner (1993) in Sari (2011) adds that lack of water availability during the generative phase has an effect on the quality and quantity of plants. Water requirements for strawberry cultivation are not too much, but they should not be short of water. Bima (2007) states that if water is given to plants in large quantities it will cause the medium to be saturated with water, so that it will cause aeration of the soil to be bad due to lack of oxygen in the soil. In addition, the water given in excessive conditions can cause the roots of plants to be disturbed to absorb nutrients and water so that it has an impact on the weight of the fruit produced.

According to Goldsworthy and Fisher (1992) there are two factors that influence the number of fruits, namely external factors and internal factors. External factors are influenced by temperature while factors are influenced by genetics. The development of plants is strongly influenced by temperature. High temperatures will result in the loss of high amounts of water, causing plants to lose large amounts of water and plants will wither. In this condition, plants tend to abort leaves and flowers for survival so that the number of fruit produced is not optimal. This is in line with the opinion of Pracaya (1994) that the number and weight of fruit are also influenced by temperature, where the temperature can cause loss of fruit and flowers so that it will affect the amount and weight of fruit produced. Maynard (1987) explained that if water stress or water deficit occurs during vegetative growth, then 
cell growth and development is inhibited, leaves become small so that only a small amount of photosynthate can be translocated to the fruit, consequently the fruit size becomes smaller.

\section{Fruit Weight Per Plant (g)}

Observation data of fruit weight per plant can be seen in Appendix 21 and the table of results of variance analysis is presented in Appendix 22. From the variance table it can be seen that the treatment of castration has a very significant effect, while the source of the seedlings shows unreal results. The average fruit weight per plant can be seen in Table 4 .

Table 4. Average Fruit Weight Per Strawberry Plant Treatment

\begin{tabular}{llll}
\multicolumn{3}{c}{ of Castration and Seed Source } \\
\hline \multirow{2}{*}{ Treatment } & Fruit Planting & \multicolumn{2}{c}{ Notation } \\
\cline { 3 - 4 } & Weight & 0.5 & 0.1 \\
\hline K0S1 & $5.04 \mathrm{~B}$ & $\mathrm{~b}$ & $\mathrm{~B}$ \\
K0S2 & $4.61 \mathrm{~B}$ & $\mathrm{~b}$ & $\mathrm{~B}$ \\
K0S3 & $5.21 \mathrm{~B}$ & $\mathrm{~b}$ & $\mathrm{~B}$ \\
K1S1 & $13.11 \mathrm{~A}$ & $\mathrm{a}$ & $\mathrm{A}$ \\
K1S2 & $10.78 \mathrm{~A}$ & $\mathrm{a}$ & $\mathrm{A}$ \\
K1S3 & $8.71 \mathrm{~A}$ & $\mathrm{a}$ & $\mathrm{A}$ \\
\hline
\end{tabular}

Note: Numbers with the same letters in the same column are not significantly different at the level of $\alpha=0.05 \%$ (lowercase) and $\alpha 0.01$ (uppercase) based on the Duncan distance test (DMRT).

From the Table, it can be seen that based on the results of the Duncan distance test the results were obtained where the treatment level to K1 (castration) showed that the fruit weight of the crop had a significant effect, very different from the other treatments. The calculation results are very different from the results on the number of stem fruits, the number of fruit sources is the one that influences while the fruit weight of the castration plant shows significant results. Where the treatment of castration and different seed sources shows all treatments using seed sources both from tillers and from tendrils, and get high yields. The results of the observations were seen in the treatment of K1S1 from the observations of $19.125, \mathrm{~K} 1 \mathrm{~S} 2$ of $20.62, \mathrm{~K} 1 \mathrm{~S} 3$ and the highest in the treatment of K1S1. This shows that the treatment of castration on various sources of seeds has an effect on the fruit weight of the crop.

\section{Fruit Production Per Plot (g)}

Production observation per plot was obtained from the sum of the total sample weights with the total weight not sampled in each experimental plot. Production per plot observation data can be seen in appendix 24 and the table of results of variance analysis is presented in appendix 25. From the variance table, it can be seen that the treatment of castration and source of seed has no significant effect on production per plot. Likewise the treatment of the combination of the two treatments had no significant effect on the amount of production per plot. Average production per plot can be seen in Table 5 . 
Table 5. Average Weight of Production Per Plot of Strawberry Plants Due to the Treatment of Castration and Seed Sources.

\begin{tabular}{lll}
\hline Treatment & \multicolumn{1}{c}{$\begin{array}{c}\text { Fruit Plot } \\
\text { Weight }\end{array}$} & Notation \\
\hline K0S1 & 90.16 & tn \\
K0S2 & 78.17 & tn \\
K0S3 & 88.28 & tn \\
K1S1 & 176.13 & tn \\
K1S2 & 143.7 & tn \\
K1S3 & 128.16 & tn \\
\hline Note $:$ tn = not real &
\end{tabular}

From Table 5 it can be seen that it is not the same as the fruit weight of the crop and the number of fruit bunches with perplot fruit weight, the results of perplot fruit weights show no significant results at all experimental levels for each treated treatment. But the highest results in the treatment based on the Table obtained all the treatment of castration on all seed sources showed high results compared to those not performed castration. The highest results were shown in treatment K1S1 (176.13), the second highest K1S2 (143.7) and the third highest K1S3 (128.16) and all three showed maximum results compared to the control treatment namely K0S2 (78.17).

In the treatment of castration does not show a significant effect on the parameters of the number of leaves, flowering period and number of stem fruit. Castration has an overall effect on fruit weight, while per plot is not significantly different, but based on tables from average per plot shows a greater production weight compared to non-castrated. This is due to the ability of nutrients from basic fertilizers to have the ability to provide nutrients to the soil during application. In the treatment of nutrient castration itself which should be used for the process of flowering and direct pollination is used for the process of fruit enlargement, where nutrients (nutrients) are used as energy for the pollination process are not used but diverted to the base of strawberry fruit formation (receptacle). Seen in Table 5 above all seed sources (tillers and tendrils) even though they did not show a very significant difference, but the fruit produced was larger than that which was not carried out by castration (annex 43)

Where in the process of fruit formation is supported by the presence of nutrients contained in the provision of basic fertilizers when application, which is given to all treatments with the same dose can meet the nutrient requirements needed by strawberry plants and absorbed and utilized properly by plants. The $\mathrm{N}$ element contained in the given fertilizer plays a role in protein constituents, so the fruit weight of all treatment levels does not show a real difference coupled with the treatment of castration to produce fruit of a larger size. While the $\mathrm{K}$ element that plays a role in the formation of carbohydrates and sugars which serves to make the quality of flowers and fruit produced will be better (Rosmarkan and Yuwono, 2002)

The application of fertilizer increases phosphorus and affects the amount of fruit per strawberry plant. This shows that the administration of basic fertilizers in all treatments can meet the needs of plants, especially for the sake of fruit formation and castration, making the fruit size bigger (Agromedia, 2007). In Table 5 above, it can be seen that the highest fruit 
weight and perplot fruit were obtained by the combination of K1S1, namely by the castration treatment from bibitanakan sources. Fruit formation requires macro nutrients, namely $\mathrm{P}$ elements and $\mathrm{K}$ elements in the optimum amount that are used to help the formation of proteins, minerals, carbohydrates and sugars and help transport sugar from leaves to fruit. If the plant lacks phosphorus elements, the plant yields in the form of flowers, fruit and seeds will decline. According to Gardner et al. (1991) states that the more transfer of food reserves (which are formed from nutrient uptake) to fruit and seeds will increase the size and quality. Rosmarkam and Yuwono, (2002) state that phosphorus is considered as the key to life because it deals with cell energy compounds (ATP) which were formed first when postforlation and photosynthesis in leaves, this is seen in plants that are castrated but not given basic fertilizer at a time application, shows the results of the same fruit weight in the control treatment without castration given the basic fertilizer (appendix 45). Castration in this study shows that the average fruit weight is better than that which is not castrated in all seed sources, although statistical calculations do not show significant results but on average fruit weight is better.

\section{Fruit Production Per Hectare (ton / ha)}

The production observation table per hectare of strawberry plants is presented in Appendix 23. From the Table it can be seen that all treatments and combinations of treatments showed unreal results. Average production per hectare can be seen in Table 6.

Table 6. Conversion of Strawberry Production with Castration and Seed Source Treatment

\section{Conversion of strawberry production with castration treatment and seed sources}

\begin{tabular}{llc}
\hline Treatment & \multicolumn{1}{c}{ Treatment } & Produ ton/ha \\
K0S1 & Without Castration & 0.5 \\
K0S2 & Without Castration & 0.4 \\
K0S3 & Without Castration & 0.5 \\
K1S1 & Castration & 1.0 \\
K1S2 & Castration & 0.8 \\
K1S3 & Castration & 0.7 \\
\hline
\end{tabular}

From the results of the calculation, for the size per hectare it can be seen the results obtained for each treatment, where the highest yield is 1.0 ton / ha which is produced by the treatment K1S1 and the lowest result is K0S2 treatment which is 0.4 tons / ha. Usually strawberry productivity reaches an average of $0.45 \mathrm{~kg}$ per plant or around 10-15 tons per hectare per year (Rukmana, 1998). 


\section{Conclusion}

1. Treatment of seed sources does not significantly affect the growth of strawberry plants (number of leaves) from different seed sources.

2. Treatment of seed sources as long as the seed has a flowering age faster than the source of seedlings from tendrils.

3. The treatment of castration and source of seeds can increase production (fruit weight of planting) compared to without castration treatment.

\section{References}

Agromedia. 2007. Petunjuk Pemupukan. Agromedia Pustaka. Jakarta.

Anonimus, 2005. Fragaria vesca. Accessed from http://repository.unhas.ac.id/bitstream /.../BAB\%20II. pdf

Ashari. S. 1995. Hortikultura Aspek Budidaya. Penerbit Univerwsitas Indonesia. Jakarta

Badan Pusat Statistik, 2012. Diakses dari Kalanaprion.blogspot.com/2013/04 strawberry.html accessed on 5 April 2013.

Bima, C. L. 2007. Pengaruh Pemberian Pupuk Kandang Ayam dan Pemberian Air Melalui Irigasi Tetes Pada Budidaya Tanaman Cabai (Capsicum annuum L). Skripsi Fakultas Pertanian Universitas Riau. Pekanbaru

Budiman, S and D. Saraswati. 2008. Berkebun stroberi secara komersial. Penebar Swadaya. Jakarta.

2010. Berkebun stroberi secara komersial. Penebar Swadaya. Jakarta.

Cahyono, B. 2003. Budidaya Stroberi. Kanisius. Yogyakarta. Accessed on books. http://google.com/books?isbn=9792120378

Darjanto and Satifah. 1984. Fisiologi Tanaman. Bina Aksara. Jakarta.

Dian, N. 2013. Pengaruh Sistem Pengairan Terhadap Pertumbuhan dan Produktivitas Beberapa Varietas Padi Sawah (Oryza sativa L.). Skripsi Fakultas Pertanian Institut Pertanian Bogor.

Direktorat Tanaman Buah. 2002. Stroberi (Fragaria sp.). Direktoral Jendral Bina Produksi Hortikultura. 5 pages.

Departemen Kesehatan RI. 2007. Manfaat Tanaman Stroberi. Diakses http://depkesri.com. accessed on 12 October 2010.

Ferdy. 2008. Kastrasi dan Hibridisasi. Diakses dari http://missrant.host22.com/ hkm-hrdywnbrg.html, accessed on 19 October 2010.

Gardner, F.P., R.H. Pearce dan R.L. Michell, 1991. Fisiologi Tanaman Budidaya. U.I. Press. Jakarta.

Gunawan, Livy Winata. Stroberi. 1996. Penebar Swadaya. Jakarta.

Ginting, S. 1991. Dasar - dasar Bercocok Tanam. Kanisius. Yogyakarta.

Gomez, A.K dan A. A. Gomez, 2005, Statistical Procedure For Agriculture Research. Jhon Wiley dan Sons. NY.

Goldsworthy, P. R. and Fisher, N. M. 1992. Fisiologi Tanaman Budidaya Tropika. Gadjah Mada University Press. Yogyakarta. 
Hanif and Hasyim, 2012 on Aswita 2007. Accessed on http://kalanaprion.Blogspot.com/ 2013/04/strawberry.html, 5 April 2013.

Kurnia, A. 2005. Petunjuk Praktis Budidaya Stroberi. PT. Agromedia Pustaka. Jakarta. 70 page.

Lakitan, B. (2013). Fisiologi Tumbuhan. Raja Grafindo Persada. Jakarta.

Maynard, G.H. 1987. The Phisiology of Plants Under Stress. Jhon wiley \& Sons, inc. New York.

Millya, A. P. 2007. Pengaruh waktu pembenaman orok-orok (Crotalaria juncea L.) dan dosis pupuk Urea pada pertumbuhan dan hasil tanaman jagung (Zea mays L.) Thesis. Universitas Brawijaya. Malang.

Pracaya. 1994. Bertanam Tanaman buah. Kanisius. Yogyakarta.

Rosmarkam, A. and N.W. Yuwono, 2002. Ilmu Kesuburan Tanah. Kanisius. Yogyakarta.

Rukmana, H. R. 1998. Budidaya stroberi dan pasca panen. Publisher : Kanisius. Yogyakarta.

Salisbury F.B. and Cleon W.R. 1998. Fisiologi Tumbuhan. Publisher IB. Bandung.

- 1992 . Fisiologi Tumbuhan. Publisher IB. Bandung.

Sari. 2011. Respon Tanaman Kentang (Solanum tuberosum L.) Terhadap Irigasi Tetes dengan Volume dan Waktu Aplikasi yang Berbeda. Skripsi Fakultas Pertanian Universitas Muhammadiyah. Malang.

Setiani, A 2007. Budidaya dan Analisis Usaha Stroberi, Penerbit Sinar Cemerlang Abadi. Jakarta

Sudarma, JH. 2013. Pembibitan Tanaman Buah. Bola Bintang Publishing. Klaten. Accessed on http://www.warintek.ristek.go.id, 2010.

Sumarna, A. 1998. Irigasi Tetes pada Budidaya Cabai. Balai Penelitian Tanaman Sayuran. Bogor.

Siswono. 2005. Skripsi . Pengaruh Giberlin GA3 Terhadap Pertumbuhan, Produksi dan Kualitas Buah Tanaman Stroberi (Fragaria vesca L.) Selly Wilova. 2008. (online). accessed on http:/ repository. unand. ac.id/eprint/5989. 24 November 2010.

Soemadi, W. 1997. Budidaya Stroberi.C.V. Aneka, Surakarta. Hal 70. http://www.trubusonline.com. No 315 February 1996.

Wiryanta. 2002. Bertanam Cabai pada Musim Hujan. Agromedia Pustaka. Jakarta. 